\title{
Fascist Femininities: Models of Womanhood in the Romanian National Legionary State
}

\author{
Mihai Stelian Rusu ${ }^{1}$
}

Recibido: 15 de junio de 2020 / Aceptado: 11 de julio 2020

\begin{abstract}
This paper aims at discerning the models of fascist femininity endorsed by the Romanian National Legionary State. It consists in a quantitative content analysis performed on articles published in the regime's official newspaper, Cuvântul, in a permanent column addressed to women. The findings point out the prevalence of the traditional model of "domestic womanhood" over the masculinized model of "warrior femalehood." This quantitative approach grounded on content analysis is complemented by a qualitative approach based on a visual analysis of women's depiction in the Legion's printed press. Visual commercials, product advertising featuring women and other depictions of female figures reveal a third, heterodox, type of womanhood that we suggest calling "Legionary chic." Based on these findings, the study concludes by pointing out the heterogeneity of the National Legionary State's politics of womanhood.
\end{abstract}

Keywords: gender roles; feminine fascism; New Woman; politics of womanhood; Romanian Iron Guard.

\section{[es] Feminidades fascistas: modelos de mujer en el Estado Nacional Legionario de Rumanía}

Resumen. Este artículo tiene como objetivo examinar los modelos de feminidad fascista respaldados por el Estado Legionario Nacional rumano. Consiste en un análisis cuantitativo de contenido realizado sobre artículos publicados en el periódico oficial del régimen, Cuvântul, en una columna permanente dirigida a las mujeres. Los resultados señalan la prevalencia del modelo tradicional de "feminidad doméstica" sobre el modelo masculinizado de "feminidad guerrera". Este enfoque cuantitativo basado en el análisis de contenido se complementa con un enfoque cualitativo basado en un análisis visual de la representación de las mujeres en la prensa impresa de la Legión. Los anuncios visuales, la publicidad de productos con mujeres y otras representaciones de figuras femeninas revelan un tercer tipo de feminidad heterodoxa que sugerimos llamar "Chic legionaria". Con base en estos hallazgos, el estudio concluye señalando la heterogeneidad de la política de feminidad del Estado Nacional Legionario.

Palabras clave: roles de género; fascismo femenino; Mujer Nueva; política de la feminidad; Guardia de Hierro rumana.

Sumario. 1. Introduction. 2. The "green" press and the National Legionary State. 3. Methodological underpinnings. 4. Models of Legionary womanhood 5. "Legionary chic" as a heterodox model of fascist femininity. 6. Conclusions: The multiplicity of Legionary womanhoods.

Cómo citar: Rusu, M. S. (2020). Fascist Femininities: Models of Womanhood in the Romanian National Legionary State. Cuadernos de Historia Contemporánea, Vol. 42: 19-38.

Lucian Blaga University of Sibiu, Romania

E-mail: mihai.rusu@ulbsibiu.ro 


\section{Introduction}

Women's entanglements with fascism were slow to make it into the agenda of fascist studies. Scholarship done in this area was distracted from focusing more intensely on the feminine underside of fascism by the muscular, flashy, and violent overside of fascist movements. Although a latecomer under the gaze of historical and sociological scholarship, the feminine face of fascism, once brought to the fore, opens up an important insight into the core of the fascist worldview by shedding light on the gender politics of these movements. After a long period of neglect, during which time scholars' attention was caught by the fascist movements' masculine trappings and muscular tonus, the mid-seventies saw a first wave of works breaking ground into a previously uncharted scholarly territory. ${ }^{2}$ When scholarship on the relationship between women and fascism eventually burst out, a decade later, it made its academic entrance in grand fashion. Works such as Claudia Koonz's Mothers in the Fatherland, Julie Gottlieb's Feminine Fascism, and Irene Guenther's, Nazi Chic?, to which other fine scholarship could be added, have come to define a still-burgeoning field of study at the intersection of gender and fascist studies. ${ }^{3}$

This study draws on the extant scholarship on the politics of womanhood in the Romanian Iron Guard, in an attempt to discern how women were imagined by the masculine leaders of the National Legionary State. The gender politics of the Romanian fascist movement has been largely neglected, as researchers have focused their attention either before or after the period between the two world wars. ${ }^{4}$ The historical parenthesis was only partially filled by scanty but valuable research. ${ }^{5}$ Drawing on discourse analysis carried out on a wide range of Legionary writings, scholars have distinguished between three models of Legionary womanhood. ${ }^{6}$ The dominant one, representing the movement's default ideological stance on the woman question, is that of "domestic motherhood." Time and again, women are called to listen to their maternal instinct and to be supportive wives for their heroic husbands by taking care of the household. Second, and in a tensional relationship with this domestic model of motherhood, stands the virago model of "warrior femalehood." This alternative, and quite conflicting, discursive strand summons women to fight for the Legion side-by-

2 Stephenson, Jill: Women in Nazi Society, New York: Barnes \& Noble, 1975; De Grand, Alexander: "Women under Italian Fascism," The Historical Journal, 19, no. 4 (1976): pp. 947-968.

3 Koonz, Claudia: Mothers in the Fatherland: Women, the Family and Nazi Politics, New York: St. Martin's Press, 1987; Gottlieb, Julie V. Feminine Fascism: Women in Britain's Fascist Movement, London and New York: I.B. Taurus, 2003; Guenther, Irene: Nazi Chic?: Fashioning Women in the Third Reich, Oxford and New York: Berg, 2004. Besides these country-specific monographies, the scholarly literature on the gendered dimension of fascism also includes comparative works that survey the topic across national borders. See, for example, Durham, Martin: Women and Fascism, London and New York: Routledge, 1998; Kevin Passmore (Ed.): Women, Gender and Fascism in Europe, 1919-1945, Manchester: Manchester University Press, 2003.

4 Bucur, Maria: "Between the Mother of the Wounded and the Virgin of Jiu: Romanian Women and the Gender Heroism during the Great War," Journal of Women's History, 12, no. 2 (2000): pp. 30-56; Massino, Jill: “Marital Roles and Relations in State Socialist Romania," Journal of Women's History, 22, no. 1 (2010): pp. 34-60; Băban, Adriana: "Women's Sexuality and Reproductive Behavior in Post-Ceaușescu Romania: A Psychological Approach," in Susan Gal and Gail Kligman (Eds.): Reproducing Gender: Politics, Publics, and Everyday Life After Socialism, Princeton: Princeton University Press, 2000, pp. 226-255.

5 Bucur, Maria: "Romania," in Passmore (Ed.): Women, Gender and Fascism in Europe..., pp. 57-78; Petrescu, Alexandra: "Women and Fascism in Romania," Postmodern Openings in Political Sciences, 2, Iași: Lumen, 2009: pp. 73-88.

6 Rusu, Mihai Stelian: "Domesticating Viragos. The Politics of Womanhood in the Romanian Legionary Movement," Fascism. Journal of Comparative Fascist Studies, 5, no. 2 (2016): pp. 149-176. 
side with their masculine fellow men in the common struggle to redeem the nation. As the young Legionary females increasingly appropriated the rhetoric of martyr heroism exhorted specifically towards the men of the Legion and started putting on the paramilitary uniforms, this development threatened the movement's patriarchal gender order. To counteract this ideologically undesired outcome, the male leadership of the movement initiated a program of "domesticating viragos" by developing a "hybrid model" of womanhood in which heroic features were subordinated to motherhood and to their domestic calling.

This paper contributes to the existing scholarship on the gender politics of fascist movements and on the Legionary models of womanhood in particular by adding a quantitative content analysis to what has been a strictly qualitative approach. It asks the question, how have women been imagined as political subjects during the National Legionary State? Moreover, if indeed we are dealing with a heterogeneous politics of womanhood, as scholars in fascist studies have claimed based on their discursive approach, which one of these models of femalehood is statistically dominant in the National Legionary State's official discourse? A methodological approach grounded in quantitative content analysis promises to yield an answer to these topics by revealing the statistical distribution of the various types of femininity promoted in the National Legionary regime. It will also provide a complementary, quantitative approach to the qualitative interpretation of the "gynopolitical project" pursued in the National Legionary State, thereby offering a comprehensive purview of the Romanian fascist regime's politics of womanhood.

\section{The "green" press and the National Legionary State}

Despite the print boom experienced by the Legionary press during the 1930s, with hundreds of newspapers and magazines from all across the country spreading the movement's word by print, the woman question has been largely neglected. ${ }^{7}$ In stark contrast to other fascist movements, which have published dedicated periodicals and magazines to attract the women readership into their ranks, such as La donna fascista (1919-1943), NS-Frauen-Warte (1933-1945), or Ustaškinja (1942-1945), there was no similar publication addressed specifically to the Romanian feminine public. ${ }^{8}$ It was only after the Romanian fascist Iron Guard assumed power and established the National Legionary State (September 14, 1940-February 14, 1941) that women finally grasped the regime's attention. ${ }^{9}$ A permanent column addressed to women, "Cuvântul Femeii" (The Woman's Word), has made its appearance in the regime's official mouthpiece, Cuvântul (The Word).

For an overview of the Legionary press, see Clark, Roland: Holy Legionary Youth: Fascist Activism in Interwar Romania, Ithaca, NY: Cornell University Press, 2015, especially chapter 5, "The Power of Print."

8 De Grand, Alexander: "Women under Italian Fascism," 19, no. 4 (1976), pp. 947-968; Rupp, Leila J.: "Mother of the 'Volk': The Image of Women in Nazi Ideology," 3, no. 2 (1977), pp. 362-379; Rory Yeomans, The Ustasha Regime and the Cultural Politics of Fascism, 1941-1945, Pittsburg: University of Pittsburgh Press, 2013.

9 The most comprehensive historical overview of the Legionary movement is provided in Armin Heinen, Die Legion "Erzengel Michael” in Rumänien. Soziale Bewegung und politische Organisation. Ein Beitrag zum Problem des internationalen Faschismus, München: R. Oldenbourg Verlag, 1986; for the National Legionary State, see Rebecca Haynes, "Germany and the Establishment of the Romanian National Legionary State, September 1940," The Slavonic and East European Review, 77, no. 4 (1999): 700-725. 
The masculine focus of the movement also meant that issues pertaining to gender were treated sporadically, here and there, within this hectic corpus of printed political literature. In this bustling field of Legionary activity, characterized by spurts of collective enthusiasm fueled and simultaneously clogged by political harassment and publishing censorship on the one side and the challenge of financial hardship on the other side, it is thus difficult to find constant attention devoted to women. As the female population was not a prime target for the Legionary propaganda, directed towards recruiting the male student youth in the movement's ranks, the leaders were not interested in developing a feminine readership. Since the social base of the movement was not counting on female elements, a permanent rubric dedicated to womanly affairs was deemed not only irrelevant, but also a waste of valuable "propaganda estate" within the highly expensive-to-print political press.

During the tumultuous early years of the movement's difficult birth and tortuous growth, from its inception in 1927 until it finally and unexpectedly managed to seize state power in 1940, the woman question was seldom paid any attention. ${ }^{10}$ Prior to this moment hailed as the "Legionary triumph," the green press was scrambling for reaching to the male readership to thicken up the movement's ranks, which left women out of its purview. It was only after the movement assumed power and established the short-lived National Legionary State (September 14, 1940-February 14, 1941), that conditions were ripe for engaging with the long-neglected feminine sector of the Romanian population now under the Legion's control. Among the chronic scarcity of sources for mapping out the Legionary view of womanhood, the permanent column for women of Cuvântul newspaper - "Cuvântul femeii" - stands out as an invaluable source for unraveling the normative model of womanhood endorsed within the Romanian fascist state. ${ }^{11}$

The history of Cuvântul follows the ebb and flow of persecution and thrive, similar to the tumultuous pathway of the Legionary movement. Founded in 1924 by Titus Enacovici, it was suppressed in December 1933 in the wake of the assassination of the Prime-minister Ion G. Duca by a Legionary death squad, the "Nicadori."12 Nae Ionescu, its director and the Legion's doctrinaire, was also arrested following Duca's violent death. The newspaper resurged in January 1938, but it was soon closed down in April the same year and its director again arrested for its open support of the Legionary movement. Ionescu will shortly thereafter die, without witnessing the newspaper triumph during the National Legionary State. On September 6, 1940, faced with territorial losses, King Carol II, the Legion's nemesis and arch-enemy, abdicated the throne in favor of his 18 years old son Mihai. His royal dictatorship thus came to an abrupt end. A week later, on September 14, 1940, the National Legionary State

10 The only notable exception is the conference held in 1935 by one the Legion's commanders on female heroism, later published as a booklet, see Gyr, Radu: Femeia în eroismul spiritual, moral şi naţional, București: Cetățuia Legionară, 1937.

11 The most comprehensive historical overview of the Legionary movement is provided in Heinen, Armin: Die Legion "Erzengel Michael" in Rumänien. Soziale Bewegung und politische Organisation. Ein Beitrag zum Problem des internationalen Faschismus, München: R. Oldenbourg Verlag, 1986; for the National Legionary State, see also Deletant, Dennis: Hitler's Forgotten Ally: Ion Antonescu and His Regime, Romania 1940-44, Basingstoke: Palgrave, 2006, pp. 52-68.

12 Rusu, Mihai Stelian: "The Sacralization of Martyric Death in Romanian Legionary Movement: Self-sacrificial Patriotism, Vicarious Atonement, and Thanatic Nationalism," Politics, Religion \& Ideology, 17, no. 2-3 (2016), pp. 249-273. 
was proclaimed, ruled by an uneasy alliance between General Antonescu and the Legionary movement now led by Horia Sima. ${ }^{13}$

Nae Ionescu's widow, who inherited the newspaper's ownership from her husband, donated Cuvântul to the Iron Guard. Cuvântul resurged, once again, on October 14, 1940, under the directorship of P.P. Panaitescu, as "The Newspaper of the Legionary Movement." Now, re-emerged as the mouthpiece of the new regime, Cuvântul finally managed to surpass in terms of circulation figures the popular newspapers such as Dimineața (The Morning) and Universul (The Universe). During Nae Ionescu's lead, Cuvântul could never reach the circulation and readership figures of Dimineața, Curentul, Adevărul, and especially Universul in the late $1930 \mathrm{~s} .{ }^{14}$ In the mid-1930s, Dimineața was having a daily edition of 100,000 printed copies, while Universul was reaching a circulation of 120,000. Cuvântul could only dream of such numbers. It was uncompetitive even in comparison to Pamfil Șeicaru's right-wing Curentul (The Current), which was issued daily in 40-50,000 printed copies, or to the leftist newspaper Adevărul (The Truth), with its 35-40,000 daily copies. One reason for this was its rather intellectual bent grounded on articles as opposed to a tabloid focus on feature reports and faits divers, championed by Universul. ${ }^{15}$ Things changed abruptly with the proclamation of the National Legionary State and the re-emergence of Cuvântul as the regime's official organ. Each of its seven daily editions now came off the presses in 120,000 printed copies, surpassing Universul as the widest circulated newspaper. ${ }^{16}$

\section{Methodological underpinnings}

This study employs quantitative content analysis for establishing the main features in terms of which the Romanian National Legionary State defined the normative models of womanhood. ${ }^{17}$ The empirical base of this study consists of 104 articles published in the column "Woman's Word" between the first number of the newly re-issued newspaper Cuvântul (No. 1, October 14, 1940) and the last number of its appearance (No. 99, January 24, 1941). The category scheme was developed inductively, as a result of a back-and-forth reading of the text materials against the theoretical framework articulated for making sense of the Legionary politics of gender. The structure of categories was gradually put together as it emerged out of a dialogical interaction between a close reading of the texts, on the one hand, and a conceptual apparatus devised in fascist studies that dealt with the feminine underside of the political movement.

13 Haynes, Rebecca: "Germany and the Establishment of the Romanian National Legionary State, September 1940," The Slavonic and East European Review, 77, no. 4 (1999), pp. 700-725.

14 Georgescu, Ioan: Din presa periodică în România, Oradea: Editura Revistei "Vestitorul”, 1936, p. 102; Samson, A.P.: Memoriile unui gazetar (1927-1937), București: Cartea românească, 1979, p. 93, p. 100; Șeicaru, Pamfil: Istoria presei, Pitești: Paralela 45, 2007, p. 312.

15 Șeicaru, Istoria presei, p. 298; Petcu, Marian: Istoria jurnalismului şi a publicităţii în România, Iași: Polirom, 2007, p. 58.

16 Sima, Horia: Era libertății. Statul Național-Legionar. Vol. I, Timișoara: Gordian, 1995: VI, 3.

17 Philip Weber, Robert: Basic Content Analysis. $2^{\text {nd }}$ edition, Thousand Oaks: Sage Publications, 1990; A. Neuendorf, Kimberly: The Content Analysis Guidebook, Thousand Oaks: Sage Publications, 2002; Krippendorff, Klaus: Content Analysis: An Introduction to Its Methodology. $2^{\text {nd }}$ edition, Thousand Oaks: Sage Publications, 2004. 
The category structure we devised is stratified along three levels of abstraction. At the top level, we have distinguished between two basic categories, constituting the fundamental gender binary of "femininity" and "masculinity." In our analysis, these opposing categories describe features of character, social roles, and patterns of behavior used to characterize the normative image of womanhood. Each of them is made up of a triptych of level 2 categories: "motherhood," "domesticity," "aesthetics" for femininity, "virile heroism," "female manliness," and "physicality" for masculinity, respectively. These level 2 concepts are still abstract categories, fairly remote from the textual empiria. They are rooted in the empirical reality (i.e., the textual empiria defined as constituting the universe of the study) through a series of level 3 subcategories (codes) that will be detailed in the section below.

\subsection{Motherhood}

The notion of "motherhood," instrumental in defining the traditional understanding of womanhood, was operationalized in four dimensions, "birth-giving," "nurturing," "nourishing," and "social motherhood" respectively. Each of these categories captures an intrinsic aspect of motherhood, as the latter was understood in the Legionary worldview.

3.1.1. Birth-giving motherhood was used for coding every textual instance where womanhood was defined through giving birth to children, women were urged to give birth as a social and moral duty, the role and status of mothers were glorified, or women were rendered as biologically destined to birthing children. An emphatic example of a sentence coded as birth-giving motherhood was Lucia Trandafir quoting Corneliu Codreanu on asserting that "the greatest glory to which a woman can strive is the glory of being a mother." 18 Or, urges summoning "the woman, as a wife and a mother, at home and in society, to take the place nature herself had wisely destined for her." 19 Other texts coded here emphasized the "sacred nature of the maternal duty," "the proud of being a mother," or birth-giving motherhood described as "the sublime calling of a woman." 20

3.1.2. Nurturing motherhood was developed as a category to account for those instances where the woman was depicted as an educator of her children, where she was praised for her naturally endowed pedagogical gifts, or where she was conjured or summoned to raise her children well since the whole future of the country hinges on the quality of maternal education. In one of the most powerful associations of womanhood with nurturing motherhood, Lola Ionescu Marița asserts that "To be a mother is to be an educator; it is at the woman's breast that Man, God's masterpiece, grows." ${ }^{21}$ The duty of mothering one's own children should not be delegated, as every mother is bound to raise her own toddlers in full accordance with the national spirit: "Romanian babies do not need foreign nurses, with or without diplomas. A

18 Trandafir, Lucia: “Tinerețea arde,” Cuvântul. Ziar al Mișcării Legionare, XVII (Serie nouă), no. 1 (14 October 1940), p. 2.

19 Marița, Lola Ionescu: “Mângâiere,” Cuvântul, XVII, no. 32 (14 November 1940), p. 2. Lola Ionescu Marița (thereafter L.I.M.) was the by far the most prolific writer in the "Women's Word" column, authoring 78 of the total of 104 articles.

20 L.I.M., "Pentru viitoare mamă," Cuvântul, XVII, no. 59 (11 December 1940), p. 2; L.I.M., "Familia," Cuvântul, XVIII, no. 92 (17 January 1941), p. 2.

21 L.I.M., "Femeia şi sportul," Cuvântul, XVIII, no. 87 (12 January 1941)p. 2. 
mother's eye and hand are sacred." 22 Mothers are also deemed to understand that correct education means gendered education: they are to "virilize boys and feminize their little girls. The former [are to be raised] as future builders [of their country], while girls as future mothers [of their nation]."23

3.1.3. Nourishing motherhood includes those messages that insisted upon a woman's maternal duty to feed her children and to care for their health and wellbeing. Time and again she is reminded that "it is the mother's duty to care for children's nourishment." Mothers are to be both guardian and feeding angels for their children: "Children ask us for nourishment, clothing, help. We shall not let our children suffer, and we shall especially not let them be frightened and scared. Let their sleep be sweet and their angels closer." ${ }^{24}$ When combined, these three dimensions of motherhood - birth-giving, nurturing, and nourishing motherhood - develop what we propose naming a maternal soteriology of the nation. Depicted in their capacity of birthing and rearing healthy children, mothers are praised as fountainheads of redemption for the Romanian nation. As birth-givers and educators of heroes, mothers will vicariously redeem the nation through the actions of their (male) offspring. Conversely, birthing and mothering future domestic housewives, by "teaching her little girl the hows of housekeeping, building in her soul the sacred love of the household, women should know that mothers are the builders of the nation." ${ }^{25}$ Either future male heroes or domestic mothers, women of today should know that what comes out their womb will keep the nation alive. It is they who by birth-giving are the biological mothers of the nation. They are the ones biologically producing and reproducing the nation. It is also them who, by child-rearing, acting as parental agents of primary socialization, are culturally reproducing the nation.

3.1.4. Social motherhood covers those messages encouraging women to extend their maternal instinct beyond the sociobiological micro-cosmos of the family to exert their mothering care over the vulnerable categories of the wider society. Although the family was glorified as the basic cell of society, Legionary ideology also considered the nation as an ethnic-cosmos, i.e. - as a Blut und Boden historical community of people facing the same collective destiny. Thus understood as a family writ large - a biological communion of souls across generations, including the living, the dead, and the yet unborn ${ }^{26}$ - women were urged to mother the nation at large through various charitable actions. Exhortations to social motherhood are intrinsically bound to what we shall call as philanthropic patriotism required from women's part, summoned to express their loyalty to the nation and love of the country in altruistic acts of social care. One such activity by which women were invited to step into the public realm was the field of social work, considered properly fit for women's helping nature. Closely related was that of nursing, continuing thus women's contribution to the Great War in times of peace. ${ }^{27}$ Women were praised for opening a canteen, where they could literally serve the country with their own hands by working in the kitchen and serving the food. Another dimension of social motherhood through acts of philanthropic patriotism was donating clothes and other useful things to the poor and

\footnotetext{
L.I.M., "Pentru viitoare mamă."

L.I.M, "Familia."

L.I.M., "Un mănunchi de sfaturi," Cuvântul, XVII, no. 37 (19 November 1940), p. 2.

L.I.M., "Îndrumări," Cuvântul, XVII, no. 34 (16 November 1940), p. 2.

Codreanu, Corneliu Zelea: Pentru legionari. $2^{\text {nd }}$ edition, Sibiu: Editura “Totul pentru Țară", 1936), p. 423.

Bucur, "Between the Mother..."
} 
needy through the Legionary Aid. ${ }^{28}$ The earthquake that hit Bucharest on November 10, 1940, killing hundreds and injuring thousands, triggered an aftershock of solidarity. "Romanian woman, Legionary woman, shall be heart and soul for the hardtried Patria." ${ }^{29}$ Shattered by natural calamity and buried under the rubble of dust and concrete, society was in a desperate need of "biblical love of the neighbor in need." Orphans and elders were also among those vulnerable groups requiring women's care. Ladies were conjured to organize charity sales for the immediate help of children and the elderly living in orphanages and shelters. ${ }^{31}$ This womanly philanthropic patriotism had an additional symbolic dimension, as it was directed not only towards the living, but also towards the dead. Sundays and during religious holidays, ladies of the Legion were invited to turn their attention towards the past and to respect the martyrs of the nation by caring for their graves and shrines (troiț) in cemeteries or at the sites where the latter were erected.

\subsection{Domesticity}

The second concept structuring the master category of femininity is that of "domesticity." Included under this rubric were all the activities and roles in which women were placed within the confines of the household (except, of course, those already coded as pertaining to motherhood).

3.2.1. Domestic servitude was used to code the textual instances where women were portrayed in menial roles within the household, such as having the domestic duty of setting the table and serving their husbands and children. Time and again, serving her family at the table is rendered as a womanly domestic ritual and duty. A full-blown pedagogy of feminine domesticity comes out from the column addressed to women hosted by Cuvântul. In this sense, an unauthored article pleads in its very title for "Preparing girls for domestic services," while another writes in praise of serving the household masters, i.e. - men. ${ }^{32}$ Women are taught that the love they receive from their master-husbands fully compensates their menial status within the household. "If in the home of her husband, she would pass like a shadow, as a slave - in his heart she would reign as a queen." ${ }^{33}$ This last quote illustrates, in emphatic fashion, the symbolic sublimation of woman in patriarchal, male-centric, societies, a process which is at the very core of the notion of domestic servitude: menial slave in the household of his master-husband, reigning queen in the strand of romantic imagination.

3.2.2. Housewifery stands for all those activities that rendered the woman as a housewife, taking care of the household and managing the domestic economy. This hallmark dimension of domesticity includes activities such as canning and pickling vegetables for winter, taking care of the vegetable garden, watering the flowers, cleaning, and housekeeping. The column addressed to women is full of practical advises on the "hows" of housewifery, ranging from suggestions on how to cut back

\footnotetext{
L.I.M., "Când vântul șueră,” Cuvântul, XVII, no. 20 (2 November 1940), p. 2.

L.I.M., "Smerenie și rugă," Cuvântul, XVII, no. 31 (13 November 1940), p. 2.

L.I.M., "Mângâiere."

L.I.M., "Daruri de Crăciun,” Cuvântul, XVII, no. 57 (9 December 1940), p. 2.

"Pregătirea fetelor pentru serviciile casnice," Cuvântul, XVII, no. 50 (2 December 1940), p. 2; L.I.M., "Spre binele copilului," Cuvântul, XVII, no. 28 (10 November 1940), p. 2.

33 L.I.M., "Creștinii se ospătează," Cuvântul, XVII, no. 73 (25 December 1940), p. 2.
} 
costs and in running the household to "how to get rid of red cockroaches," "how to fill cavities in the flooring," and "how to remove mildew stains from clothes." ${ }^{34}$

3.2.3. Kitchenry covers the gastronomical side of domesticity. Although tangential with domestic servitude and nurturing motherhood as both of these have to do with either serving the food at the table or feeding children, kitchenry is nevertheless a sui generis category. This category was used for coding the themes depicting the woman in the kitchen with the pan and a ladle in her hands. It is as a cook for the entire family that she is receiving various cooking tips and culinary advice, "how-tos" and even "what-tos" (including specific instructions on what to cook for tomorrow, in terms of the season and religious obligations such as fasting). Besides the housewifery and kitchenry topics scattered throughout the column addressed to ladies, the "Woman's Word" usually included a subrubric whose heading reads as "domesticities" (gospodărești). It was within this quasi-permanent subrubric of the column that most of the culinary recipes and practical advice on the hows of housekeeping were given. They were coded to either "housewifery" or "kitchenry" depending on their primary focus on housework or cooking respectively, although the great majority were suggestions for recipes to be prepared for tomorrow's dinner.

3.2.4. Domestic handicraft provided the label for coding those themes conjuring women to produce within the household goods for themselves and their families. Emerging from these messages trying to persuade women to manufacture clothing items and household goods with their own hands is a domestic feminine work ethos. Its not so hidden agenda is two-fold: first, to keep women from entering the workforce outside of the household and thus to maintain them under the watchful patriarchal gaze of masculine hegemony; second, to transform them into economically productive units that would contribute to the income of the household. Women are told not to buy from fancy shops on Smârdan and Lipscani (buzzling commercial streets in the center of Bucharest dominated by Jewish merchants). Instead, they should make their clothes, inspired by the traditional motifs of folk fashion..$^{35}$ Folk chic is to be preferred to the bourgeois fashion styles. Why should she waste money on factory-made clothing when she is by nature a gifted seamstress? "If man's [sic!] greatest discovery was fire, a perfect achievement of the woman was made the day the most skillful of our great-grandmother made a hole in a fishbone and started sewing." ${ }^{\prime 36}$ Shedding light on the gendered distribution of mythological fame, Prometheus's female counterpart was thus an anonymous woman who discovered the needle. The crucial difference being that while fire freed humans from the whims of nature, the needle fastened women in a condition of domestic captivity.

\subsection{Aesthetics}

The third and final constitutive dimension of the master concept of femininity regards the aesthetic aspects of womanhood. It has to do with how the woman presents herself in front of her husband, society, and God. This category is structured on three coordinates, corresponding to a woman's physical appearance ("natural aesthetics"), her fashion code and dressing style ("clothing decency"), and inner self ("spiritual beauty").

\footnotetext{
34 L.I.M., "Cum și în ce fel? Un mănunchi de sfaturi şi răspunsuri,” Cuvântul, XVII, no. 65 (17 December 1940), p. 2.

35 L.I.M., "Despre pălării," Cuvântul, XVII, no. 5 (18 October 1940), p. 2.

36 L.I.M., "Clacă de lucru," Cuvântul, XVII, no. 47 (29 November 1940), p. 2.
} 
3.1. Natural aesthetics was used for coding those themes conveyed in the column by which women were instructed to embrace a normative image of physical appearance defined by simplicity and naturalness. The column is riddled with appeals to modesty and its authors launch constantly into a bitter diatribe against cosmetics, toiletry, and other artificial means of beautification. Over and over again, the "Woman's Word" vituperates against "the rouge trinity" of modern chic: "red makeup, red lipstick, red nail polish." ${ }^{37}$ What women need to understand is that the foundation of beauty lies instead in an organismic trinity: "sound health, good blood flow, and a good movement of bowels." ${ }^{38}$ The modern woman, beautified excessively by resorting to makeup trickeries, is a gloomy perversion of natural female beauty. "And in that buzzling torrent of hustle and bustle, there is the woman. It terrifies me to describe this woman. Dyed in the wildest of colors, with their hair contorted in the guise of a Kikish horn, with their poor eyebrows mercilessly plucked out, with their blacken and unctuous eyelashes, with lips covered under a thick layer of red stain, with red nails, while the heels of their shoes are kilometric long." ${ }^{39}$ But, underneath her heavy mask, "her soul is darkened, choked by weeds, and squirming." ${ }^{40}$ Despite this vitriolic diatribe on modern coquetry, one is surprised to come across what appears to be a soft apology of cosmetics. The columnist argues against those radical views according to which make-up is tantamount to hypocrisy, since it is a womanly art of deceitfulness. If this is so, "what about clothing?" asks the author. "Make-up is sometimes an aesthetic duty. Indeed, it is not vanity, but humbleness. If we would have been perfect already, we would not correct ourselves. It is altruism, since we are doing it for the other." ${ }^{41}$

3.2. Clothing decency is the twin category of "natural aesthetics," with which it forms the normative outer image for womanhood. Continuing the tirade targeting beautified bodily appearance through the use of extensive makeup, the column grapples with the dressing style adopted by women. Luxury is taken by assault in the moral crusade for imposing clothing decency. "A Legionary woman," asserts Cornelia Novacu giving voice to the masculine consensus over feminine fashion style, "preserves decency in her outer appearance." ${ }^{42}$ She is to be the opposite of fashionista. She should stay away from Lipscani, "the street where all the baits of luxurious bad taste have glittered year after year in the light of thousands of volts." ${ }^{43}$ Instead of fancy hats and other haute coutures bought from the Jewish shops on Lipscani, she better covers her head with homemade kerchiefs decorated with folk motifs. ${ }^{44}$ In a programmatic statement for folk chic, clothing decency, and against anti-luxury, Legionary New Women are urged to "shake off from modern fashionable lifestyle," as it leads them astray from her maternal destiny. ${ }^{45}$

3.3. Spiritual beauty completes the picture of how a woman is to present herself to others by adding the inner dimension to the two outer dimensions already presented. There are two sub-dimensions that constitute the main theme of spiritual beauty.

\footnotetext{
L.I.M., "Îngrijirea mâinilor," Cuvântul, XVIII, no. 90 (15 January 1941), p. 2.

Ibidem.

Novac, Cornelia: "De ce atâta nepăsare," Cuvântul, XVII, no. 45 (27 November 1940), p. 2.

Ibidem.

L.I.M., "Îngrijire și înfrumusețare," Cuvântul, XVIII, no. 91 (16 January 1941), p. 2.

42 Novacu, Cornelia: "Nicoleta / O circulară a Nicoletei Niculescu," Cuvântul, XVII, no. 7 (20 October 1940), p. 2.

43 L.I.M., "În Lipscani," Cuvântul, XVII, no. 62 (14 December 1940), p. 2.

44 L.I.M., "Despre pălării."

45 Năstase, Ioana: "Pentru noi, noile legionare," Cuvântul, XVII, no. 12 (25 October 1940), p. 2.
} 
The first, religious dimension, including topics such as piety and religious devotion, spiritual purity, and inwards cleanliness, regards the presentation of the female self towards God. While the second, moral dimension, covering the themes of propriety, politeness, good-breeding, and social decorum, concerns how women present their inner selves to others, at home and in society at large.

\subsection{Virile heroism}

Injunctions to male-like feats of heroism constitute a basic dimension of the second master concept, that of "masculinity." Scattered throughout the column addressed to women are praises of self-sacrifice and heroic martyrdom. The Legionary hallmark of a tantalizing cult of death is revealed in these frantic exhortations to martyrdom. ${ }^{46}$ Two different currents can be discerned as making their ways within the "Woman's Word" column. First, a rather traditional gender perspective that relegates women to a passive stance of heroic widowhood. Cast in this role, women are either bereaved mothers, wives, daughters, and sisters bravely facing the loss of their beloved man, or admiring bystanders to their heroic martyrdom who contribute actively to their devout veneration as political martyrs. This is the case, for instance, of Cornelia Novacu's all-male martyrology praising the memory of the Nicadori. ${ }^{47}$ In another article, the same author writes a mixed-gender martyrology, focusing in particular on the feminine tradition of dying for the Legion. Along Ion I. Moța and Vasile Marin - the proto-martyrs of the movement and its ultimate icons of self-abnegation $^{48}$ - the article praises Nicoleta Nicolescu, Lenutica Bagdad, Olimpia Zeana, and Lucia Grecu for their martyr's death. ${ }^{49}$ It is this line of female martyrdom that highlights the second current running through the column, placing the woman on par with her fellow man in terms of her willingness to undergo heroic martyrdom. Liliana Protopopescu, another sporadic columnist in the "Woman's Word" writes of a six years old girl who sings along with her two little brothers Radu Gyr's Hymn of the Legionary Youth, chanting "Death, only Legionary death / [It is the most beloved wedding of weddings]." ${ }^{50}$ This celebration of death and call to political martyrdom, rendered metaphorically as a wedding, appeals to femina virilis, imagining the Legionary woman as a virago "forgetful of her sex" and her womanly weaknesses. ${ }^{51}$ That is to say, a virile model of womanhood, best embodied by Nicoleta Nicolescu, who has undergone the full transition, first from "virgo to virago," and then from virago to virgin-martyr. ${ }^{52}$

46 Rusu, Mihai Stelian: "Staging Death: Christofascist Necropolitics during the National Legionary State in Romania, 1940-1941," Nationalities Papers: The Journal of Nationalism and Ethnicity, forthcoming (2020), DOI: https://doi.org/10.1017/nps.2020.22

47 Novac, Cornelia: “Ani de luptă,” Cuvântul, XVII, no. 48 (30 November 1940), p. 2.

48 Săndulescu, Valentin: "Sacralised Politics in Action: The February 1937 Burial of the Romanian Legionary Leaders Ion Moța and Vasile Marin," Totalitarian Movements and Political Religions, 8, no. 2 (2007), p. 259269.

49 Novac, Cornelia: “Să ne rugăm lui Dumezeu," Cuvântul, XVII, no. 38 (20 November 1940), p. 2.

50 Protopopescu, Liliana: “...Și arhanghelul din cer,” Cuvântul, XVII, no. 27 (9 November 1940), p. 2.

51 Schulenburg, Jane Tibbetts: Forgetful of Their Sex: Female Sanctity and Society, ca. 500-1100, Chicago: The University of Chicago Press, 1998.

52 Corrigan, Kirsty: Virgo to Virago: Medea in the Silver Age, Newcastle Upon Tyne: Cambridge Scholars Publishing, 2013. 


\subsection{Female manliness}

Besides a heroic will to martyrdom, the Legionary virago should also express a second manly feature of character under the form of "feminine manhood" (bărbăție). Codreanu is once again quoted as the ultimate source shrouded in the aura of authority, asking for "a woman, but with a character of great manhood." ${ }^{53}$ The same Lucia Trandafir, in her capacity of Commander of the Women's Corps, called the Legionary woman to be "ruthless with herself, [yet] lenient with others." ${ }^{54}$ In everything she does, she is to display the same manly fortitude. Discipline, hard work, fight, and order are the four manly virtues that shall govern her daily activities. ${ }^{55}$ Even Lola Ionescu Marița, who usually authored articles hailing the cult of domesticity, breaks her regular pattern and leaves her imagination prey to the figures of "handsome girls, sturdy and manned-up" (chipeșe fete, voinice şi bărbate). ${ }^{56}$ When they are not urged to "man up" themselves, women are asked to man up their men from their supportive roles of mothers, wives, sisters, and daughters. This runs like a red thread throughout the series of articles written by Emilia Bogdan, who also asks of women to break free from the bondage of "feminine nature." Pointing out women's proclivity to gossip, chit-chat, and idle talk, she blasts against those who brought with them within the Legion itself "our bag of all too feminine weaknesses, the bondage of our spiritual life." ${ }^{57}$ And as the Legion is a school of character meant to nurture the New Man through a moral transfiguration that will reshape their very human nature, women will also have to undergo a similar anthropological revolution.

\subsection{Physicality}

The first two dimensions structuring the master category of womanly masculinity dealt with her inner spiritual makeup (female manliness understood as moral fortitude) translated in overt behavior (virile heroism as expressed in her willingness to undergo martyrdom). Physicality, its third and final component, has to do with the outer, bodily constitution of the Legionary woman. Great emphasis is placed upon "physical education" as a means of shaping up the feminine body. Practicing sports - gymnastics and ski - is recommended to women in order to keep their bodies fit and healthy. ${ }^{58}$ Obesity - "the horror of us all" - can be successfully fought through religious fasting and practicing sports..$^{59}$ Nevertheless, the cheers to practice sports stopped short of instituting a policy of muscular womanhood. Despite relentless encouragement to work out their bodies, physical education was more often than not put in the service of motherhood, conjugality, and domesticity. Trying to react in the face of the mounting conservative critique against women engaging in sports activities, Lola Ionescu Marița publishes a material in which she dismantles any opposition between traditional womanhood and practicing sports: "Sport is not an enemy of marriage and certainly not of motherhood.

\footnotetext{
53 Trandafir, "Tinerețea arde."

54 Trandafir, Lucia: “Cetățuia,” Cuvântul, XVII, no. 15 (29 October 1940), p. 2.

55 Lucia Trandafir, "Legionara și disciplina," Cuvântul, XVII, no. 34 (16 November 1940), p. 2.

56 L.I.M., "Sfârșit de toamnă," Cuvântul, XVII, no. 42 (24 November 1940), p. 2.

57 Bogdan, Emilia: "Celelalte robii," Cuvântul, XVII, no. 46 (28 November 1940), p. 2; Emilia Bogdan, "Pentru noi legionarele," Cuvântul, XVII, no. 51 (3 December 1940)p. 2.

58 L.I.M., “Ca să întâlnim toamna," Cuvântul, XVII, no. 29 (11 November 1940), p. 2; L.I.M., "Pe zăpadă," Cuvântul, XVII, no. 76 (30 December 1940), p. 2; L.I.M., "Îngrijirea mâinilor," Cuvântul, XVIII, no. 90 (15 January 1941), p. 2.

59 L.I.M., "Echilibru alimentar," Cuvântul, XVII, no. 48 (30 November 1940), p. 2.
} 
Sportswomen are delightful mothers." ${ }^{\circ 0}$ In another edition of the newspaper, women are reminded "not to forget gymnastics. Female arms remain forever beautiful because they are always on the move, working, beating the carpet, shaking the pillow, turning the mattress. ${ }^{\prime 61}$ In any case, through physical education, practiced either directly via sports and gymnastic exercises or indirectly via domestic activities, "woman has to gain 'vigor' without losing her own nature." 62

\section{Models of Legionary womanhood}

The results of the thematic content analysis are displayed in the table below, which also allows for a panoramic view of the category scheme used to organize conceptually the empirical data.

Table 1 . The category system and the results

\begin{tabular}{|c|c|c|c|c|c|c|c|c|c|c|c|c|c|c|}
\hline $\begin{array}{r}\text { Level of } \\
\end{array}$ & \multicolumn{14}{|c|}{ Category name } \\
\hline $\begin{array}{r}\text { Level } 1 \\
\text { categories }\end{array}$ & \multicolumn{11}{|c|}{ Femininity } & \multicolumn{3}{|c|}{ Masculinity } \\
\hline $\begin{array}{r}\text { Level } 2 \\
\text { categories }\end{array}$ & \multicolumn{4}{|c|}{ Motherhood } & \multicolumn{4}{|c|}{ Domesticity } & \multicolumn{3}{|c|}{ Aestheticity } & \multirow{2}{*}{ 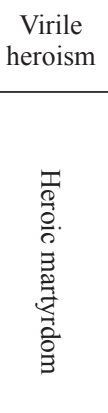 } & \multirow{2}{*}{ 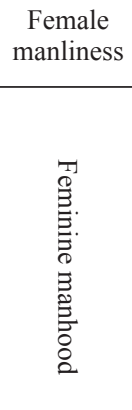 } & \multirow{2}{*}{ 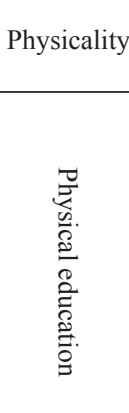 } \\
\hline $\begin{array}{r}\text { Level } 3 \\
\text { subcategories } \\
\text { (codes) }\end{array}$ & 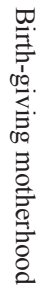 & 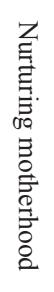 & 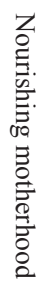 & 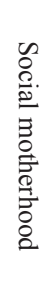 & 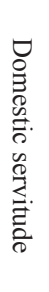 & 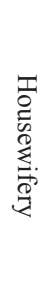 & 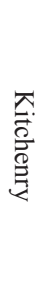 & 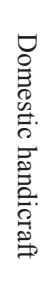 & 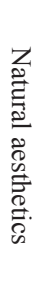 & 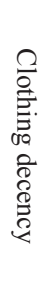 & 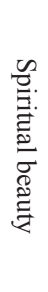 & & & \\
\hline Specific count & 12 & 14 & 20 & 15 & 16 & 12 & 65 & 14 & 8 & 11 & 11 & 7 & 9 & 6 \\
\hline Total count & \multicolumn{11}{|c|}{$198(90.0 \%)$} & \multicolumn{3}{|c|}{$22(10.0 \%)$} \\
\hline
\end{tabular}

What is immediately striking about the data distribution is the absolute prevalence of "femininity" roles and features, totaling 90 percent of the coded items, in stark contrast to the categories belonging to "masculinity," which accounts for only 10 percent. If masculinity features are relatively equally distributed, within the realm of femininity traits, the situation is rather imbalanced. "Domesticity" reigns supreme accounting for almost half of total occurrences (48.64\%), followed by "motherhood" with over a quarter $(27.73 \%)$, and "aesthetics" with 13.64 percent. The conclusion flowing smoothly from the data presented in the table pinpoints towards a cult of domesticity, within which the duty of the Legionary housewife is to busy herself with the cradle and the ladle, i.e. - the tasks of motherhood, child-rearing, housekeeping, and kitchenry. She is to be obedient to her husband/father/brother and embrace her menial condi-

\footnotetext{
L.I.M., "Femeia și sportul,” Cuvântul, XVIII, no. 87 (12 January 1941), p. 2.

L.I.M., "Îngrijirea mâinilor."

L.I.M., "Exercițiul fizic,” Cuvântul, XVII, no. 45 (27 November 1940), p. 2.
} 
tion of domestic servitude. She should take care of her inner self, and foster an inner, spiritual beauty polished through moral and sentimental education on the one hand and religious piety on the other. When presenting her outer, physical self towards the others, especially when she steps out of the sacred temple of the family home over which she is the reigning queen to venture herself into the profanities of men's public world, she is to dress herself in the clothes of decency and to put on her face the cosmetics of natural aesthetics. It is only scarcely and incidentally that women are confronted with messages urging them to adopt traditionally male-associated lines of action, such as a worked-out muscular body, moral fortitude, and heroic martyrdom. Although these exhortations to "man up" are by no way absent, and their emotional impact upon the feminine readership must have been stronger than a rather conventional article providing them with culinary suggestions on what to cook for dinner tomorrow.

The Legionary normative image of womanhood wavers between two very different ideal types, situated at the extremities of the femininity-masculinity spectrum. They also stand at opposite ends of the conservative-revolutionary spectrum in terms of political roles. The first normative model of Legionary womanhood is the ideal type of the domestic woman, standing at the femininity and the conservative ends of the two analytical spectrums. She is conceived of in the traditional roles of mother and wife, while her activities are largely restricted within the confines of the household. She is cast in a rather conservative politic position, since she will play only a passive, supportive role in the Legionary revolution, which falls entirely within men's realm of responsibility. Facing her from the opposite ends, situated at the masculinity and revolutionary extremities of the two spectrums, is the warrior woman, the Legionary virago. Contrary to the domestic model of womanhood, the Legionary virago is to partake in the political struggle side-byside with their fellow men comrades and are to adopt the same standard of virile heroism expressed in the readiness to undergo martyric death. Hardly reconcilable, these two models of Legionary womanhood both struggled for achieving hegemonic status within the movement's gender politics. Young women such as Nicoleta Nicolescu, who was the Commander of the Legion's Feminine Section from 1933 to 1936 and died a martyr's death during the persecutions against the movement initiated by King Carol II in 1939, pursued a more militant agenda. Challenging the conventional gender lines set forth by the masculine elite of the Legion, Nicolescu envisioned a model of virile womanhood that threatened to undermine the traditional gender order. Although this androcentric ideal of a Legionary virago, as embodied by the figure of Nicoleta Nicolescu and her "Nicolettes" who followed her martyric exampla in dying for the movement, finds some ground within the column, the general message addressed to the female readership of the newspaper leans heavily towards promoting the model of domestic womanhood. There is thus a domestic skewness in the distribution of data regarding the normative image of womanhood in the Legionary State's official newspaper, favoring traditional motherhood over heroic martyrdom as appropriate attributes of women.

\section{5. "Legionary chic" as a heterodox model of fascist femininity}

Delving into the pages of Bunavestire de Duminică (December 1940-January 1941), a weekly magazine which appeared in only eight issues during the short-lived National Legionary State, a slightly different picture of womanhood emerges. This was one of the few Legionary publications to house a permanent column addressed to 
female readership specifically. Besides the column whose heading was "Woman at home and outside" (Femeia la ea acasă și în lume), the magazine was advising women on topics ranging across beauty and aesthetics, style and fashion, health and wellness, as well as keeping them informed on the novelties of high-life, trendiness, and news about Hollywood movie starlets. In order to brandish its Legionary standing, the first issue of the magazine features the portrait of Corneliu Zelea Codreanu on the cover. ${ }^{63}$ But his iconic image is soon challenged by a very different model of masculinity. A column featuring "the romanticized life of a movie star" presents Robert Taylor as the new Hollywood idol, who took the movie world by storm with his "Adonis-like physic" and cinematic charisma. He is praised for his performance from the blockbuster The Lady of the Camellias, in which he starred with Greta Garbo. In another illustration, he is shown all suited up in a fancy restaurant with Barbara Stanwyck lighting up his cigarette. ${ }^{64}$ These figures are praised for their social success, flamboyant lifestyle, sophisticated tastes, and romantic conquests. Elevated as role models for the general readership to emulate, these gender models undermine the already established Legionary ideals of masculinity and femininity. With Robert Taylor and Greta Garbo regarded as sex symbols instead of Corneliu Codreanu and his wife Elena, the gender models undergo a shift from the heroic male and domestic female to the Hollywood Casanova and the movie starlet femme fatale.

This shift is most visible in the conception of womanhood. If in the column of $\mathrm{Cu}$ vântul, women are warned not to go near the shops of the old town, portrayed as places of feminine perdition, the column from Bunavestire de Duminică invites them to go window shopping. "It's Saturday afternoon and you are all free. Why wouldn't you go out, strolling with no rush for an hour or two, on Calea Victoriei and Lipscani street?"65 It will be fun and she will not spend money, as she has children to feed, but she will at least get in tune with the latest fashion. Window shopping on Lipscani will allow her to make her own models by refurbishing her old dresses after the fashionable style. "An elementary coquetry is necessary," the conclusion comes. On the same page, women are advised to change their outmoded pajamas with gracious nightdresses made out of silk. That the Legionary ideology has developed a fuzzy concept of womanhood is revealed in that this homemade, artisanal haute couture is paradoxically mingled with advice to handcraft peasant-like traditional clothing items. It is not uncommon for one issue of the column to conjure its female readership to follow the fashion trend, while the next issue to exalt the virtues of needle-working rustic pieces of clothing and viciously to condemn "the aberrations of foreign eccentricities passing as refinement."

This confusion in the conception of Legionary womanhood in provided by another recurring column of the magazine that teaches its female readership "What every housewife/woman needs to know." When addressing to its readers as housewives, women are advised on what to wear within the household and on how to fix squeaky shoes.$^{67}$ In contrast, when it addresses its readership qua women, they are taught how to do the catwalk. A beautiful feminine walking is the one in which

63 Bunavestire de Duminică, 1, no. 1 (1 December 1940): cover page.

64 "Viața romanțată a unei vedete de cinema: Robert Taylor," Bunavestire de Duminică, 1, no. 1 (1 December 1940), p. 27.

65 Mioara M.: “O cochetărie elementară,” Bunavestire de Duminică, 1, no. 1 (1 December 1940), p. 28.

66 Dana, Laetiția: "Lucrul de mână," Bunavestire de Duminică, 1, no. 3 (15 December 1940), p. 21.

${ }_{67}$ "Ce trebuie să știe o gospodină... Ținuta de interior," Bunavestire de Duminică, 2, no. 7 (12 January 1941), p.19. 
the knees are softly rubbing each other as the legs seem to follow an invisible straight line.$^{68}$ We can imagine her walking with swaying hips in a fashion spree on a bustling shopping street, without forgetting to take with her "a small vanity case filled with the powder flapjack, the rouge lipstick and blusher, the comb and the puff." The beauty toolkit should be completed by a clean handkerchief and a vial of cologne. ${ }^{69}$

They are still to take their motherhood seriously, as biological destiny, but they can do it with style. It is the notion of a Legionary chic that stands behind the image of womanhood in these press materials. Urges to clothing decency and visual modesty as part and parcels of an ascetic lifestyle give ways to callings for feminine coquetry. The world war that just started does not have to hamper feminine fashion from shining at the soirées, tea parties, balls, and stage shows. In spite of the war, women are still entitled to "adornments, glittering, [and] taste" behind the front lines at these fashionable events. ${ }^{70}$ In another deviation from the Legionary orthodoxy, women are given advice on how to beautify themselves for "their husbands and lovers," "71 suggesting the possibility of a love relationship outside the institution of marriage. Such a reference is inconceivable in the column of Cuvântul, which had articulated a stricter image of traditional womanhood. High praises are given to screenings of Alexandre Dumas' The Lady of the Camellias and Abbé Prévost's Manon Lescaut, well known for the loose morals of their anti-heroines. The latter is reviewed as an "exquisite accomplishment." 72

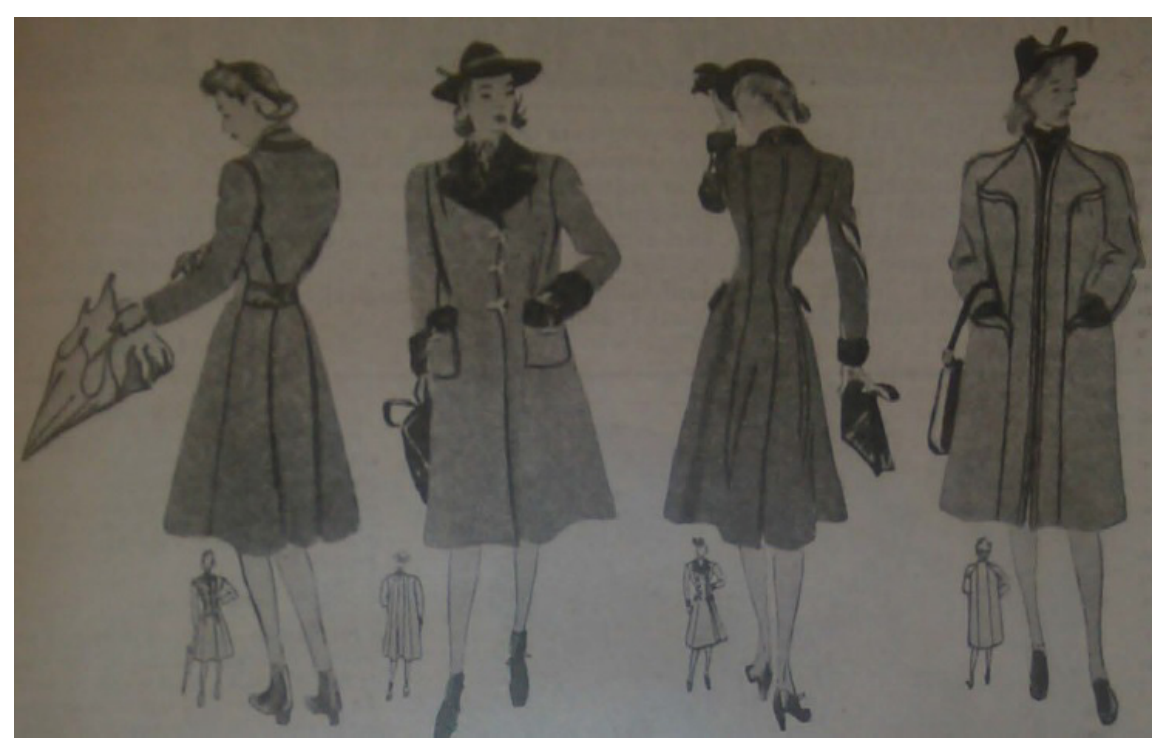

Figure 1: "Legionary chic" "73

${ }^{6}$ “Ce trebuie să știe orice femeie... Îngrijiți-vă mersul,” Bunavestire de Duminică, 2, no. 8 (19 January 1941), p. 24.

69 Mioara, "Carnet feminin," Bunavestire de Duminică, 2, no. 8 (12 January 1941), p. 26.

70 "Podoabe, strălucire, gust...," Bunavestire de Duminică, 2, no. 6 (5 January 1941), p. 23.

71 "Frumusețea dvs. doamnă," Bunavestire de Duminică, 1, no. 2 (8 December 1940), p. 13, emphasis added.

"Film. Ce credem despre: 'Manon Lescaut'," Bunavestire de Duminică, 1, no. 2 (8 December 1940), p. 26.

“Garderoba de iarnă,” Bunavestire de Duminică, 1, no. 3 (15 December 1940), p. 27. 
It is surprising to find, in a magazine whose subtitle read as "The Weekly Illustrated of the Romanian Family," even in the humor page, jokes making fun of Romanian women's promiscuity. In one such a joke, "Girls of Today," a young lady dressed up in a backless evening dress dancing sensually in the moonlight with a young man says to him, "Joey, dear, you're not the same as yesterday." To which his dancing partner replies, "You bet. It's Tim now." 74 The jocular mood does not spare sacred topics either. A naked Adam covered only with a fig leaf is portrayed trying to seduce a sensual looking half-nude Eve. "Ma'am, do you allow me to found humankind?"75

The image of this "other," heterodox and non-normative model of femininity emerging alongside the two orthodox models of womanhood (domestic and virago) from the Legionary press is even more sharply outlined by the display advertising featuring women. Looking at how women are depicted in visual materials published in the Legionary press can open up new insights into how women were visually imagined. Despite the column specifically addressed to them, women are seldom present in the Legionary iconography. Feminine figures do appear, instead, predominantly in newspaper advertising, where they are either portrayed in traditional roles as domestic housewives or shown in modern depictions as coquettish ladies lusting after a bourgeois lifestyle. A visual analysis of the feminine iconography featured in the official "green press" published during the National Legionary State reveals that women were portrayed in four major types of display advertising.

The first category is made of a) advertising for medicines and health products meant to alleviate pain and enhance a comfortable lifestyle. In commercials for Bayer pharmaceuticals, for instance, smiling young women are used to conveying the idea of a painless, comfortable existence, free of any unnecessary suffering. What this type of advertising transmits is the bourgeois ideal of a comfortable life that runs headlong to the much-praised Legionary ideal of an ascetic existence, a virtuous life full of self-imposed deprivations. It goes very much against Codreanu's pedagogy of suffering, according to which the Legion is a "school of pain" and self-sacrifice. ${ }^{76}$

A second category includes b) advertising for household appliances, depicting women in the traditional roles of domestic housewives doing the cleaning. Nevertheless, even though it endorses a traditional view on women's role and status, this type of advertising promotes a modernizing agenda, as it offers a mechanized rendition of housewifery. A third category consists of c) advertising for American moving pictures running in Bucharest cinemas, most often accompanied by movie reviews. It is here that another dimension of the orthodox model of womanhood, i.e. - the visual modesty of women's physical presentation, is brought under question. Hollywood starlets are displayed in lascivious postures, bordering the erotic, as they indulge in romantic and flirtatious behavior. As opposed to the companionate love fit for conjugal relationships praised by the Legionary cult of family life, these images develop a cult of passionate love, as expressed by Armand Duval's love for the courtesan Marguerite Gautier, or by the chevalier des Grieux for the prostitute Manon Lescaut.

Finally, a fourth category is made of d) advertising for clothing and fashion. Images pertaining to this category can be divided into three sub-categories: i) folk chic, ii) luxury chic, and iii) sensual chic (see Fig. 2 below). The first of these is fully consonant with the

\footnotetext{
"Humor. Fetele de azi," Bunavestire de Duminică, 1, no. 8 (19 January 1941), p. 25.

"Primul păcat," Bunavestire de Duminică, 1, no. 8 (19 January 1941):, p. 25.

Codreanu, Corneliu Zelea: Cărticica șefului de cuib. $2^{\text {nd }}$ edition, București: sine nomine, 1934, p. 49.
} 
Legionary politics of womanhood, as images belonging to this sub-category depict women in domestic roles wearing traditional clothing inspired from peasant fashion. Luxury chic, in contrast, advertises haute couture, including such fancy goods as fur coats, leather jackets, and fine fabrics. Advertising for luxury feminine clothes already clashes with the Legionary ideal of woman modesty. The ultimate antinomy is reached, nevertheless, in men's paramilitary fashion. It is intriguing to find within the pages of Cuvântul-the official organ of the National Legionary State - advertising to "luxury Legionary shirts." cially more so as the green shirt was revered as a quasi-sacred item that had to be gained through personal sacrifice and suffering, not bought from the market as deluxe apparel. One had to prove him/herself of being worthy of wearing the green shirt. Emilia Bogdan, writing in Cuvântul's column for women, voices the Legion's mystical tinge by saying that "the green shirt is an odajdie [i.e. liturgical garments wore by Orthodox priests during religious service], a symbol of heroic life. This is why it is an impiety to make a fashion out of its wearing." ${ }^{78}$ This was echoing Codreanu's poignant warnings of a circular issued in 1936, drawing attention on what he dubbed as "green shirt abuse." He was troubled that the success of the movement brought with it the cost of desacralizing the green shirt by its wearing in "frivolous postures and in unworthy places" such as in barrelhouses, bistros, and clubs. "Green shirts are our 'odajdie'. They are to be worn on holidays only." ${ }^{\text {"79 }}$ History repeated itself after the establishment of the National Legionary State, when green shirts have become, once again, a fashionable status symbol. The third sub-category, sensual chic, includes images depicting young women wearing lingerie and other sexy outfits, such as negligées, nylon stockings, and satin nightclothes. Time and again, these visuals depicting young women scantily clothed violently contrast with the Legionary cult of female chastity.
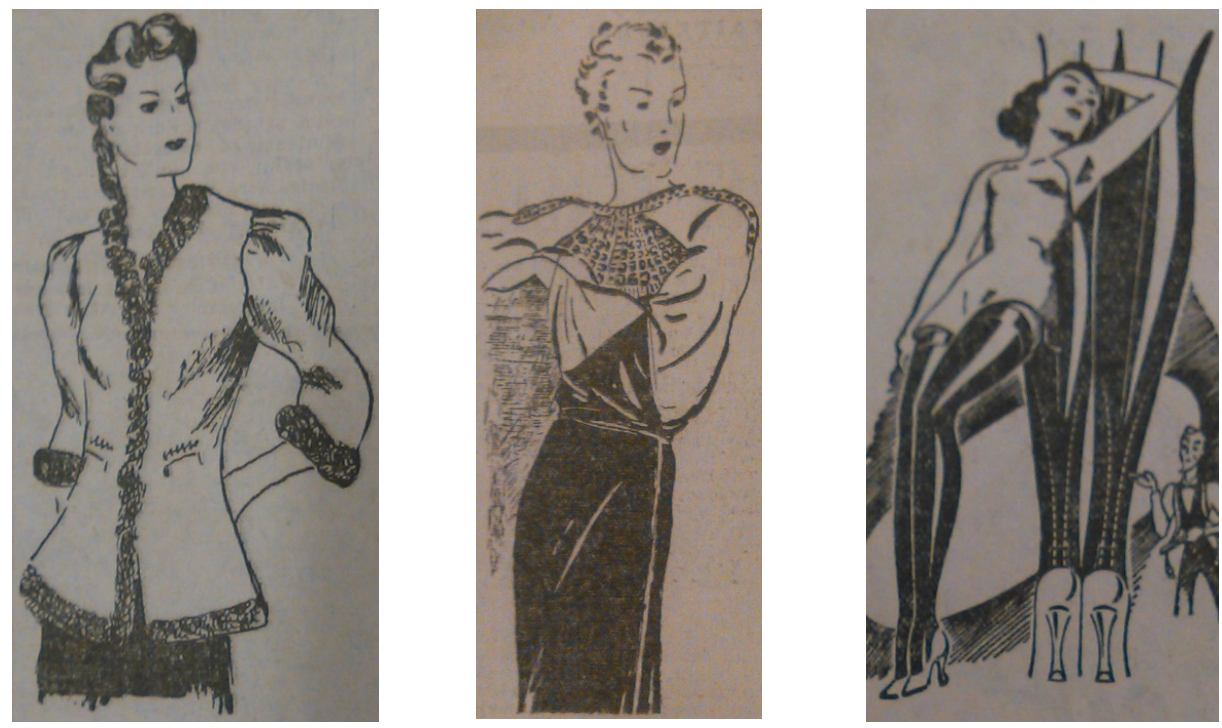

Figure 2. "Folk chic," "luxury chic," and "sensual chic"80

77

78

79 Codreanu, Corneliu Zelea: "Circulara Nr. 41" issued on 21 September 1936, in Circulări și manifeste, 19271938, München: Colecția “Europa”, 1981, pp. 87-90, 89.

80 [Folk chich] "Cațaveica," Cuvântul, XVII, no. 27 (9 November 1940): 8; [Luxury chic] Cuvântul, XVII, no. 17 (20 October 1940): 2; [Sensual chic] Cuvântul, XVII, no. 60 (12 December 1940): 10. 
This heterodox, counter-model of femininity promoted within the official green press forces us into rethinking the models of Legionary womanhood along more complicated line. Doing justice to the multifaceted nature of Legionary femalehood requires that we sophisticate our theoretical frame of reference by adding an additional element to the rather simplistic two-dimensional model. Our conceptual frame of reference can be restructured into a three-dimensional one by adding the traditional-modern dimension alongside the femininity-masculinity and the conservative-revolutionary spectrums.

Table 2. Typological matrix of Legionary womanhood

\begin{tabular}{|l|c|c|c|}
\hline & Domestic woman & Virago & Legionary chic \\
\hline (F)emininity-(M)asculinity & $\mathrm{F}$ & $\mathrm{M}$ & $\mathrm{F}$ \\
\hline (C)onservative-(R)evolutionary & $\mathrm{C}$ & $\mathrm{R}$ & $\mathrm{C}$ \\
\hline (T)raditional-(M)odern & $\mathrm{T}$ & $\mathrm{T}$ & $\mathrm{M}$ \\
\hline
\end{tabular}

Source: Author's own elaboration

\section{Conclusions: The multiplicity of Legionary womanhoods}

Our findings consolidate the current consensus prevailing among the scholars working at the triple interface between fascist, gender, and fashion studies. Recent studies have challenged the received view about the monolithic nature of totalitarian regimes, revealing their inner tensions leading to ideological contradictions, policy ambiguity, and power struggles. Simultaneously, scholars working in the tradition of Alltagsgeschichte have pointed out to the collage of "multiple ambiguities" existing at the grass level of everyday life in totalitarian states such as Nazi Germany. ${ }^{81}$ In her groundbreaking work focused on fashioning German women into the "Nazi chic," Irene Guenther flashed out the misleading nature of the stereotypical duality of conceiving womanhood during the Third Reich as either "a Brunhilde in uniform or a dirndl-wearing, chubby farmer's wife." 82 Our own analysis brings out a similar conclusion. Albeit far from establishing a political regime settled down into a totalitarian state, the short-lived National Legionary State was nevertheless affected by a similar indecisiveness in imagining the Romanian woman. The result of this wavering was a multiplicity of conceptions that ultimately obscures the Legionary politics of womanhood.

In this study, we have inquired into the Legionary politics of womanhood by looking specifically at how the Romanian National Legionary State had imagined the model type of female. The content analysis of Cuvâtul's permanent column dedicated to the newspaper's feminine readership revealed two models of normative womanhood, reflecting the ideological ambivalence in the Romanian Iron Guard's vision of gender. Scholars working at the intersection of gender and fascist studies have pointed out the dual nature of fascist politics of womanhood. Fascist imagina-

\footnotetext{
${ }^{81}$ Peukert, Detlev: Inside Nazi Germany: Conformity, Opposition and Racism in Everyday Life, New Haven: Yale University Press, 1987, p. 243.

82 Guenther, Nazi Chich?, p. 18.
} 
tion concerning women was split between a conservative model of domestic motherhood and a heroic model of warrior femalehood. Although the latter model finds some grounds in the column addressed to women, the quantitative content analysis we performed highlights a domestic skewness, i.e., the prevalence of messages promoting domestic motherhood as a normative model for Romanian women. Moreover, by extending the textual analysis bounded to Cuvântul's permanent column for women to include a visual analysis focused on advertising featuring feminine figures, we identified a third type of Legionary womanhood which we suggest calling "Legionary chic." This third type makes a heterodox model that runs completely against the grain of the official gender politics endorsed by both the Legionary movement and the National Legionary State. Neither a traditional housewife nor a virago warrior, it flagrantly transgresses the Legion's sumptuary ethos designed to curb extravagant expenses and promote an ideal of "functional beauty." 